\title{
NESTOR, IGUAL ZEUS NO CONSELHO: SABEDORIA, NARRAÇÃO E EXPERIÊNCIA NA ILÍADA
}

Francisco Gabriel Soares da Silva

\begin{abstract}
RESUMO
Nestor, personagem homérico, figura o ancião que participou de inúmeros combates: viu, ouviu e viveu muitas coisas. Pode-se dizer que Nestor, com sua velhice, é um sábio. Sua sabedoria advém das experiências que o formaram e da autoridade que é legada aos homens ao envelhecerem. Essas características, da personagem homérica, são destacadas por Walter Benjamin em "O narrador - considerações sobre a obra de Nikolai Leskov".
\end{abstract}

Palavras-chave: Nestor. Conselhos. Narrador

\section{NESTOR, EQUAL ZEUS AT THE COUNCIL: WISDOM, NARRATION AND EXPERIENCE IN ILIAD}

\begin{abstract}
Nestor, Homeric character, figure the old man who participated in numerous battles: saw, heard and experienced many things. It can be said that Nestor, with his old age, is a sage. His wisdom comes from the experiences that formed and authority that is bequeathed to men as they age. These characteristics, the Homeric character, are highlighted by Walter Benjamin in "The narrator consideration of the work of Nikolai Leskov."
\end{abstract}

Keywords: Nestor. Council. Narrator. 
Para o pensador alemão, a sabedoria é forjada no véu da tradição, no seio das comunidades pré-capitalistas, é a experiência o elemento de mediação da formação do sábio. Este que outrora ouviu atentamente seus velhos, incorporou tudo à sua experiência, soube ser sábio ao ouvir. A velhice é o ponto alto da autoridade de um homem no mundo antigo, e por isso Nestor é ouvido, e suas palavras consideradas com grande estima. O guerreiro, que não mais combate, leva suas experiências aos homens e reis que combatem por Agamenon: Nestor é por excelência um conselheiro. A personagem se afigura, para Benjamin, como um narrador nato. Admitindo, a partir do debate construindo no cerne da obra benjaminiana supracitada, que uma das capacidades que distingue um grande narrador é a capacidade de dar conselhos. Para Walter Benjamin, dar conselhos é menos dar uma resposta do que colaborar para a continuidade de uma história. Em "O narrador" o homem moderno está espoliado da capacidade de dar ou receber conselhos. Isso ocorre, entre outros fatores, devido ao desenvolvimento do modo de produção capitalista, que reconfigura os modos de relação entre o homem e a natureza.

Se Nestor foi formado a partir dos costumes de seu povo, podendo assimilar as experiências que foram legadas de pai para filho, podemos admitir que há uma certa unidade presente no mundo antigo. Mas, para Benjamin, o homem na modernidade é um indivíduo: aquele que se encontra isolado. Nesse sentido, pretendemos problematizar os aspectos que separam Nestor (e sua tradição) do indivíduo moderno.

\section{Quem é o narrador?}

É possível compararmos Walter Benjamin à figura do coelhinho da Pascoa que encontramos ainda hoje nos ditos populares. Conta-se que o coelho esconde os deliciosos ovos de chocolate, que ele mesmo fábrica, para divertir as pessoas. Os ovos podem ser de quem os encontrar. Onde procurar? Em toda parte. Benjamin nos dá uma pista de onde procurar pelos chocolates, 
nos mostra seu texto, O narrador: considerações sobre a obra de Nikolai Leskov de 1936, que funcionará como um mapa, sem deixar de ser um grande quebra-cabeça.

No texto intitulado Experiência e Pobreza (1933), Benjamin vem demonstrar uma compreensão de experiência. ${ }^{1}$ Esse elemento é o que formava os homens e os inseria em uma determinada cultura. Também instaura uma certa unidade entre os membros das comunidades précapitalistas. Mas devido as novas reconfigurações do modo de existência a partir modernidade, sobretudo a partir da ascensão do capitalismo e do desenvolvimento técnico, a atrofia da experiência se torna latente.

Em O narrador, Walter Benjamin vem expor a conformação da arte narrativa a partir de um contista russo: Nikolai Leskov. Quando Benjamin olha para Leskov, vê nele a figura de um narrador, mas ocorre um processo difuso. O semblante do narrador se distancia de nós - de nosso tempo - no ponto em que as relações humanas se alteram. Leskov é de nós distanciado pelo fim da arte de narrar. Não há mais uma atmosfera que permita a efetivação da arte de narrar pelo mesmo motivo que Benjamin denuncia a atrofia da experiência. $O$ que é feito pelo pensador, é aproximar os traços e elementos constitutivos dos escritos de Leskov com os elementos que permitiam a efetividade da arte de narrar.

\footnotetext{
${ }^{1}$ Walter Benjamin propõe, a partir das significações do alemão, uma distinção clara e decisiva entre experiência e vivência. Pois bem: enquanto Erfahrung é compreendida como a experiência real - ou a experiência autêntica -, aquela à qual se propaga pela oralidade, que liga o indivíduo a uma cultura; essa que faz com que haja um reconhecimento e sentimento de comunidade, completude e sentido. No entanto, Erlebnis se apresenta - apenas - enquanto vivência. São as coisas da vida que passam diante dos olhos, os sabores que rapidamente somem do paladar. Vivência, é o sentimento que habita dentro de um autômato. Esse que não é dotado de vida não pode, "naturalmente", ceder aos sentimentos, dado que esses lhes são alheios e desnecessários. Wille Bolle (2009. P. 840), em nota ao Livro M da Passagens, sintetiza essa distinção afirmando que "Erfahrung (do verbo erfahren, que originalmente significa "viajar", "atravessar") pressupõe tradição e continuidade, Erlebnis, que é algo mais espontâneo, implica em choque e descontinuidade.". Jeanne Marie assevera que "Benjamin situa neste contexto o surgimento de um novo conceito de experiência, em oposição aquele de Erfahrung (Experiência), o de Erlebnis (Vivência), que reenvia a vida do indivíduo particular, na sua inefável preciosidade, mas também na sua solidão. Essa interiorização psicológica é acompanhado por uma interiorização especificamente espacial: a arquitetura começa a valorizar, justamente, o "interior". A casa particular torna-se uma espécie de refúgio contra um mundo exterior e hostil" (2013. p. 59).
}

Mestrando em Filosofia no CMAF (Mestrado Acadêmico em Filosofia) da Universidade Estadual do Ceará (UECE). Brasileiro, residente em Fortaleza -CE. Email: 
É anunciado em $O$ narrador que a experiência de narrar está em vias de extinção. Isso nos bastaria para abordarmos dois componentes da narrativa. Esta arte só pode se dar, primeiro, por meio da experiência, ela que se efetiva em meio a uma relação de pertencimento a uma dada comunidade e à natureza humana e física, onde sobrevive um sentimento de continuidade e de sentido imanente na vida, que interliga experiência, trabalho artesanal e oralidade e onde não se pode negligenciar o gestual e o corpóreo. Poderíamos reportar-nos ao modo de vida grego (ou outro tipo de civilização antiga). Segundo, a experiência era acessada por meio dos cultos, atividades religiosas e por meio das histórias eram passadas aos jovens com experiência. A cultura e os costumes eram oralmente transmissíveis.

Existe então uma relação de coexistência entre experiência e narração em Walter Benjamin. Só é possível narrar aquilo que se torna matéria da experiência. Devido ao desenvolvimento do capitalismo, a vida perde aspectos que se mantinham inviolados nas comunidades pré-capitalistas. $O$ espirito de comunidade é convertido em individualismo, em interiorização: o ser e o mundo são dois agora, e estão separados.

Lukács, em A Teoria do Romance, nos relata que a palavra indivíduo só se torna possível em uso apenas na modernidade. ${ }^{2}$ Na modernidade a vida se torna frenética, as pessoas correm de um lado para o outro nas cidades, sem que isso obedeça a um sentido aparente. Mesmo sendo todos iguais, não conseguem se reconhecer em nada e muito menos no outro ser humano com quem se esbarra na rua. A existência começa a perder sentido. Esses elementos fazem com que a experiência possa, cada vez menos, ser evocada, inicia-se um processo de atrofiamento. Narração para Walter Benjamin é a capacidade e intercambiar experiências. Então se a narração necessita da experiência, na modernidade a narração começa a entrar em crise.

\footnotetext{
${ }^{2}$ O herói da epopeia nunca é, a rigor, um indivíduo. Desde sempre considerou-se traço essencial da epopeia que seu objeto não é um destino pessoal, mas o de uma comunidade. $E$ com razão, pois a perfeição e completude do sistema de valores que determina o cosmos épico cria um todo demasiado orgânico para que uma de suas partes possa tornar-se tão isolada em si mesma, tão fortemente voltada a si mesma, a ponto de descobrir-se como interioridade, a ponto de tornar-se individualidade (LUKÁCS. 2007, p. 67).
} 
Por mais familiar que seja seu nome, o narrador não está de fato presente entre nós, em sua atualidade viva. Ele é algo de distante, e que se distancia ainda mais. Descrever um Leskov como narrador não significa trazê-lo mais perto de nós, e sim, pelo contrário, aumentar a distância que nos separa dele. Vistos de uma certa distância, os traços grandes e simples que caracterizam o narrador se destacam nele. Ou melhor, esses traços aparecem, como um rosto humano ou um corpo de animal aparecem num rochedo, para um observador localizado numa distância apropriada e num ângulo favorável. Uma experiência quase cotidiana nos impõe a exigência dessa distância e desse ângulo de observação. É a experiência de que a arte de narrar está em vias de extinção. São cada vez mais raras as pessoas que sabem narrar devidamente. Quando se pede num grupo que alguém narre alguma coisa, o embaraço se generaliza. É como se estivéssemos privados de uma faculdade que nos parecia segura e inalienável: a faculdade de intercambiar experiências. Uma das causas desse fenômeno é óbvia: as ações da experiência estão em baixa, e tudo indica que continuarão caindo até que seu valor desapareça de todo. (BENJAMIN, 1985, 197)

Um fator que acelerou esse processo de extinção da arte narrativa é o papel que vem desempenhar a primeira guerra mundial. Este acontecimento é evocado por Benjamin tanto em Experiência e Pobreza quanto em O Narrador. A primeira grande guerra de caráter mundial tem uma inovação: há uma mobilização da técnica para a destruição do corpo humano. São criadas armas de destruição em massa, há uma desumanização da própria essência da guerra e sua forma de combate.

Os combatentes, aqueles que vão ao campo de batalha, sofreram um grande choque ao perceber que não eram homens que guerreavam contra homens. As maquinas destruíam qualquer alma viva pelo caminho. Ninguém sabia o que os atingiria até os atingir. A guerra gerou um cenário em que, segundo Benjamin, a única coisa que permanecia inalterada eram as nuvens no céu. Mesmo a guerra pode ser incorporada à experiência, é o que faz Homero. Há sempre muito o que se falar. Mas os combates voltavam mudos do campo de batalha, traumatizados. "Voltavam mais pobres em experiências comunicáveis" (BENJAMIN, 1985, 198).

\section{Duas escolas narrativas}


Walter Benjamin relata que as melhores narrativas são aquelas que trazem a experiência como legado, destacando-se as narrativas que são passadas de pessoa a pessoa por meio da oralidade. Benjamin identifica duas escolas de narradores que nascem desse processo. Uma delas pode ser personificada na figura de um viajante ou nômade. Este que passara por muitas terras, conhece povos e crenças, acresce a sua bagagem histórias de cada lugar em que esteve.

A experiência the é passada sob a forma de contos e causos, que incorpora à sua vida como coisa sua. Em cada povoado ouve o que the contam, deixando nesses lugares histórias de outras localidades que vivenciou. É aquilo que é narrado que enriquece sua narrativa ouvindo e incorporando-lhe costumes, crenças, causos e artes. Alcíno indaga Odisseu na epopeia homérica: "[...] dize-me uma coisa falando sem rebuços; por onde vagueaste, a que países arribaste no mundo? Fala-me dos homens e das cidades bem construídas [...]." (HOMERO, 100). Odisseu se apresenta, ele narra suas aventuras. Conta as terras por onde passou e apresenta as situações que o conduziram à desgraça de perder-se do caminho. Odisseu lega aos ouvintes do palácio a sua experiência.

A segunda escola de narradores se aproxima na medida em que se afasta da primeira. Esse viajante em algum momento irá se assentar, neste átimo nasce o semblante do agricultor sedentário. Este que cuida da terra e nunca saiu de seu lugar também é um grande narrador. A sua formação se dá ouvindo, em sua juventude, seus pais e avôs. Eles Ihe repassavam histórias que haviam recebido de outrem em sua linhagem. Ou mesmo ouviram de algum viajante, que em troca de comida e hospedagem lhes legara suas histórias.

Benjamin usa de imagens e nos arriscaremos a observa-las mais de perto. Ao olharmos para a tradição grega podemos ver dois importantes ícones que se tornaram base moral para essa cultura. É possível aproximar a figura de Homero a do viajante. Não entraremos no mérito da sua existência, pois o que importa é o que se constrói, oralmente deste. Conta-se que Homero era uma 
poeta cego que acompanhou toda a guerra de Troia, apesar de cego era viajante, era um contador de histórias. A segunda escola podemos aproximar a Hesíodo, que era um simples agricultor embora um grande narrador. Ambos, por meio das musas ${ }^{3}$, evocam as histórias que formaram os gregos.

\begin{abstract}
A experiência que passa de pessoa a pessoa é a fonte a que recorreram todos os narradores. E, entre as narrativas escritas, as melhores são as que menos se distinguem das histórias orais contadas pelos inúmeros narradores anônimos. Entre estes, existem dois grupos, que se interpenetram de múltiplas maneiras. A figura do narrador só se torna plenamente tangível se temos presentes esses dois grupos. "Quem viaja tem muito que contar", diz o povo, e com isso imagina o narrador como alguém que vem de longe. Mas também escutamos com prazer o homem que ganhou honestamente sua vida sem sair do seu país e que conhece suas histórias e tradições. Se quisermos concretizar esses dois grupos através dos seus representantes arcaicos, podemos dizer que um é exemplificado pelo camponês sedentário, e outro pelo marinheiro comerciante. $\mathrm{Na}$ realidade, esses dois estilos de vida produziram de certo modo suas respectivas famílias de narradores. Cada uma delas conservou, no decorrer dos séculos, suas características próprias. (BENJAMIN, $1985,197)$
\end{abstract}

Esses dois tipos de narradores, ou essas escolas, como ilustra Benjamin, não vivem independentes entre si. Elas se interpenetram. Aquele que viaja ouvindo e contanto histórias de outras localidades, ou compartilhando suas experiências, um dia irá fixar-se em alguma terra. É possível que esse viajante se torne um agricultor, que compartilhará com seus filhos e netos, ao fim do dia de trabalho, as experiências pelas quais passou, ouviu e delas se apropriou.

\title{
30 peso do conselho
}

É possível ainda ver essa relação, entre as escolas de narradores, nos artífices da idade média. As oficinas tinham um mestre que havia sido formado nalguma arte visitando oficinas e aprendendo ofícios com mestres. Nesse processo de aprendizagem, enquanto se fabrica algo, a boca do mestre está livre na pratica do oficio em que as mãos, experientes, trabalham.

\footnotetext{
${ }^{3}$ Divindades da mitologia grega que quando evocadas auxiliam na inspiração. Elas ajudam a contar histórias. Estariam ligadas não somente a inspiração, mas também a memória.

Mestrando em Filosofia no CMAF (Mestrado Acadêmico em Filosofia ) da Universidade Estadual do Ceará (UECE). Brasileiro, residente em Fortaleza -CE. Email: 
Além de repassar a arte, o mestre repassa para os jovens aprendizes histórias que ouviu em suas andanças, ou trazidas por outrem. No futuro esses aprendizes se assentaram em algum povoado e passaram adiante o que thes foi repassado. Os movimentos dos mestres e a atenção dos aprendizes participavam da paciência. A mesma paciência em que nutria a semente que seria árvore.

\footnotetext{
"Antigamente o homem imitava essa paciência" [...] já passou o tempo em que o tempo não contava. O homem de hoje não cultiva 0 que não pode ser abreviado." Com efeito, o homem conseguiu abreviar até a narrativa. (BENJAMIN, 1985, 206)
}

Dentro dessa relação se encontra um elemento que Walter Benjamin julga muito importante: repassar também um ensinamento pratico, "é uma das características de muitos narradores natos" (BENJAMIN. 1982, 200). Benjamin cita uma serie de escritores alemães que se enquadrariam como narrados desse calibre, tais como Gotthelf, Nodier, Hebel. Estes repassavam ensinamentos de agronomia, possíveis perigos da iluminação a gás e informações de caráter cientifico.

Logo, poderíamos atribuir a narrativa um valor utilitário. "Essa utilidade" segundo Benjamin (1985, 200), "pode consistir seja num ensinamento moral, seja numa sugestão prática, seja num provérbio ou numa norma de vida - de qualquer maneira, o narrador é um homem que sabe dar conselhos". Um conselho é construído no amago da experiência.

Na narrativa há uma construção exemplar, há uma forte presença de um senso prático. O que são os contos de fadas? Que papel as fábulas construíram historicamente? Antes de serem livros impressos, materialmente falando, eram histórias que tinham morada nos ditos populares ancorados nas línguas salivadas que traziam e ainda hoje trazem - com muito menos intensidade hoje - um ensinamento, uma lição "moral".

Aquele que teve experiências tem autoridade para aconselhar, por isso é quase sempre um velho, ou um homem que soube ouvir os velhos e tornar as experiências deles coisa sua. Existe um proverbio que diz que se torna 
inteligente ao aprender com as próprias experiências, mas só se torna sábio se souber ouvir as experiências de outrem e aprender com elas. "Os sábios aprendem com os erros dos outros, os tolos com os próprios erros e os idiotas não aprendem nunca," diz um provérbio chinês.

$\mathrm{Na}$ llíada de Homero, texto riquíssimo e culturalmente importante para o povo grego antigo, podemos ver claramente o caráter do conselho quando olhamos para Nestor. Este é um ancião, que em juventude foi um grande guerreiro, mas que hoje com sua experiência aconselha aos guerreiros aqueus $^{4}$. A ele todos ouviam, pois sabia das coisas, das guerras e dos homens.

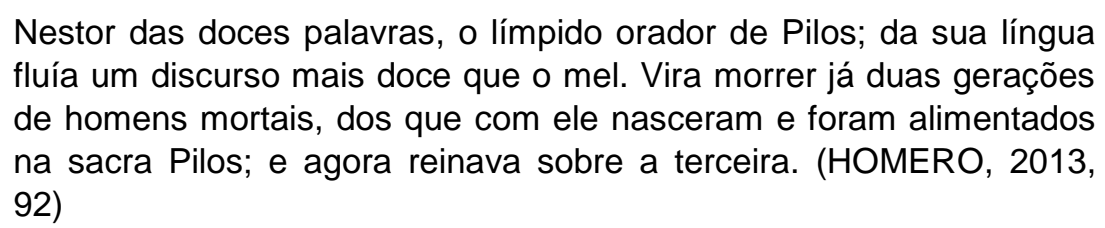

A guerra de Tróia, narrada por Homero na llíada, é a história de rapto, belezas, honra, heróis, reis, deuses, poderes e desejos. Mas é também a construção dos costumes que forjariam os gregos enquanto povo. Há uma tradição que aponta Homero como simples compilador de uma série de contos presentes entre aqueles que viriam a ser os gregos. Há quem defenda que o próprio Homero presenciou todo o desenrolar da guerra. Esse debate é construído por Carlos Alberto Nunes, na introdução da sua tradução da llíada. Para nossa pesquisa, é de valor muito irrisório tais avaliações de teor histórico, ou mesmo de validação quanto a questão homérica.

Independente da veracidade dos fatos, um elemento se destaca enquanto questão: é possível que no cerne dos elementos literários da llíada possam apresentar-se os costumes que ditavam os passos dos homens dos gregos? Nesse sentido, nos propomos a analisar o papel que o ancião Nestor desempenha durante toda a narrativa homérica. A personagem é um velho que viu e viveu inúmeras coisas. Tentaremos então evidenciar qual o peso dessa

\footnotetext{
${ }^{4}$ Ora Homero chama aqueus ou argivos aqueles que viriam a formar o povo grego. 
figura para a epopeia em questão, bem como para a cultura grega em formação.

Qual a necessidade de se levar um velho senhor para a guerra? Esta é uma indagação muito pertinente. O que faz um velho, além de lembrar e lembrar de novo e mais uma vez tudo o que viveu? Com a sua velhice contava antigas histórias de vitórias para animar a alma dos guerreiros, "assim os incitava o ancião, conhecedor de guerras antigas" (Canto IV, 152). Para Walter Benjamin, este é um elemento dos mais importante para a figura do narrador. Um excelente narrador é aquele que soube ouvir os seus velhos, e pode se apropriar de uma experiência individual, de quem lhe conta, mas que também é coletiva. O que é narrado é construído dentro de uma tradição, um objeto coletivo que perpassa cada indivíduo dentro de uma comunidade.

O status de ancião é para Nestor uma posição privilegiada. Os velhos carregam consigo o peso da experiência. A experiência, além de um aspecto cronológico alternado entre o ver, ouvir e sentir, é o elemento que forma os homens em sua sabedoria. Se é sábio porque teve experiências que enriqueceram suas escolhas. Mesmo o homem que fez as piores escolhas na vida é um homem sábio, sabe dizer aos jovens quais caminhos não trilhar. Essa é uma diferença entre o jovem mancebo e o velho: a experiência. Um sabe muito, outro sabe muito pouco, mas a sabedoria pode ser repassada pela palavra em forma de conselho ou narrativa.

Ancião, prouvera que, à semelhança do coração no teu peito,
também os teus membros te obedecessem e fosse firme a tua força!
Mas a velhice que chega a todos te oprime. Quem dera que outro
tivesse a tua idade, e que tu próprio fosses um dos mancebos!" A ele
deu resposta Nestor de Gerênia, o cavaleiro: "Atrida, muito quereria
eu ser aquele que fui quando matei o divino Ereutálion. Mas não é de
uma vez que aos homens os deuses dão todas as coisas. Nessa
altura era eu um mancebo; agora sobreveio a velhice. Mas
permanecerei entre os cavaleiros; dar-lhes-ei coragem com as
minhas decisões e palavras; é esse o privilégio dos anciãos.
Combaterão com lanças os jovens lanceiros, mais novos que eu e por
isso mais confiantes na sua força.(HOMERO, 2013, 152)

Saber dar bons conselhos é um elemento que Benjamin destaca em 0 narrador - considerações sobre a obra de Nikolai Leskov. Aconselhar é não tão 
somente transmitir um ditame, "faça isso", "haja de tal forma que obterá frutos". Algo se antecede. Saber aconselhar é saber sugerir a continuação de uma história. Só recebe um bom conselho aquele que soube expor verbalmente a questão sobre a qual se necessita aconselhamento. "Convém frisar aqui que a capacidade de dar bom conselho é tão valorizada quanto a façanha militar" (JONES, 2003).

Não à toa que os momentos de conselhos em que Nestor intervém, com sua experiência e sabedorias, são sempre espaços assembleários. Os homens problematizam a questão de como proceder na guerra diante de determinados fatores. Inicialmente, após a chegada dos aqueus ao litoral troiano, podemos ver esse cenário quando Agamêmnon decide se apropriar de Briseida de forma gananciosa. O rei decerto recebeu muitos presentes, espólios de guerra, mas sua ganância evoca o que seria uma primeira ira de Aquiles.

Inicia-se então, em meio a assembleia, uma afronta e troca de acusações. Por um lado Agamêmnon, requerendo mais presentes e de outro Aquiles querendo manter aquilo que é seu. E em meio a as fortes efusões apaixonadas, ergue-se entre os homens todos Nestor:

\begin{abstract}
Assim falou o Pelida, atirando para o chão o cetro cravejado de adereços dourados, sentando-se ele próprio em seguida. Quanto ao Atrida, continuava encolerizado. Então entre eles se levantou Nestor das doces palavras, o límpido orador de Pilos; da sua língua fluía um discurso mais doce que o mel. Vira morrer já duas gerações de homens mortais, dos que com ele nasceram e foram alimentados na sacra Pilos; e agora reinava sobre a terceira. Bem-intencionado, assim se dirigiu à assembleia: "Ah, como é grande a desgraça que à Acaia sobreveio! Na verdade se regozijariam Príamo e os filhos de Príamo, e todos os outros Troianos se alegrariam no coração, se soubessem de todo este conflito entre vós ambos, vós que entre os Dânaos sois excelsos no conselho e na luta. Ouvi-me! Sois ambos mais novos do que eu. Pois já eu com homens mais valentes que vós me dei - e nunca esses me desconsideraram. De resto nunca homens assim eu alguma vez verei. [...] Mas eles ouviam os meus conselhos e obedeciam às minhas palavras. Obedecei também vós, pois o melhor é obedecer. Que não procures tu, nobre embora sejas, tirar-lhe a donzela, mas deixa-a estar: foi a ele primeiro que os Aqueus deram o prêmio. Quanto a ti, ó Pelida, não procures à força conflitos com o rei, pois não é honra qualquer a de um rei detentor de cetro, a quem Zeus concedeu a glória. (HOMERO, 2013, 92)
\end{abstract}

Mas "Aquiles nunca acatou conselhos de ninguém; lutará quando quiser, e nada se pode fazer para alterar isso" (JONES, 2013, 8), talvez seja essa a Mestrando em Filosofia no CMAF (Mestrado Acadêmico em Filosofia) da Universidade Estadual do Ceará (UECE). Brasileiro, residente em Fortaleza -CE. Email: 
sua desgraça. Não soube ouvir as palavras de sabedoria do velho Nestor. Aquiles, encolerizado, quase em prantos recorre a mãe para rogar junto a Zeus que castigue os aqueus em nome de Agamêmnon. Zeus acaba atendendo ao pedido suplicado por sua mãe em meio a humilhação.

Zeus evoca o Sonho para enviar uma mensagem turva para o Rei, para que avance com as tropas naquele momento, que seria propício à vitória certa. "Nestor, a quem entre os anciãos mais honrava Agamêmnon. Assemelhandose a ele, assim the falou o sonho divino" (HOMERO, 104). As palavras, menos em sono, mesmo não sendo reais, carregavam o peso que Nestor apregoou em suas costas com o passar dos anos. Agamêmnon não podia negligenciar essa mensagem de Zeus.

Ao ancião são atribuídos vários adjetivos quanto a sabedoria do conselho: "Nestor, o límpido orador de Pilos", "Nestor das doces palavras". É certo que a outros personagens é atribuída, não com um peso menor, tais adjetivações. Como "Ulisses, igual de Zeus no conselho". O próprio Zeus é considerado principal referência, humana e divina, de sabedoria. Nestor, que por volta do Canto XV, é acordado por Ulisses em meio a um ataque Troiano roga aos céus pelos Aqueus, e "assim falou, rezando; e alto trovejou Zeus, o conselheiro, em resposta à prece do ancião" (HOMERO, 2013, 361).

O papel que o velho guerreiro desempenhara na batalha de Tróia, será o de modelo de sábio grego. O homem sábio é aquele que sabe aconselhar, pois para isso, carrega consigo o peso da idade. Quando jovem, Nestor jamais poderia ser dotado de sabedoria, na velhice não seria necessário pegar em armas. Os jovens mancebos o ouviriam, e carregariam a experiência que Nestor Ihes legaria.

Mas Benjamin denuncia em seu tempo um processo de decaimento de conselhos. Não há quem saiba dar ou receber conselhos, pois não sabemos narrar. Esse processo ocorre a partir do desenvolvimento técnico industrial. Para ser mais claro, não sabemos dar ou receber conselhos pelo fato de não conseguirmos mais comunicar experiências. As experiências, cada vez mais deixam de ser comunicáveis. 
Aconselhar seria para Walter Benjamin como a capacidade de dar sugestões para a continuidade de uma história do que simplesmente responder a uma pergunta. Existe uma brincadeira infantil, com resquícios dessa prática que se enquadraria como "saber dar um conselho". Faz-se uma roda com todos acomodados ao chão, onde alguém inicia uma história com uma frase e a pessoa ao lado continua.

\begin{abstract}
Mas, se "dar conselhos" parece hoje algo de antiquado, é porque as experiências estão deixando de ser comunicáveis. Em consequência, não podemos dar conselhos nem a nós mesmos nem aos outros. Aconselhar é menos responder a uma pergunta que fazer uma sugestão sobre a continuação de uma história que está sendo narrada. Para obter essa sugestão, é necessário primeiro saber narrar a história (sem contar que um homem só é receptivo a um conselho na medida em que verbaliza a sua situação). $O$ conselho tecido na substância viva da existência tem um nome: sabedoria. A arte de narrar está definhando porque a sabedoria - o lado épico da verdade - está em extinção. Porém esse processo vem de longe. (BENJAMIN, 1985, 200)
\end{abstract}

\title{
4 Narração, notícia e romance
}

A partir do desenvolvimento técnico das forças produtivas, é possível ver os indícios do declínio da arte de narrar. Para Benjamin, seu ápice é a criação do romance, enquanto forma literária. Isso se dá principalmente pelo fato de haver uma grande mudança na forma, que se diferenciará da narrativa. Enquanto a narrativa se efetiva por meio da oralidade, o romance se afirma no livro, por meio da escrita.

Construamos uma distinção entre narrativa (destacando-se a epopeia) e romance. Sigamos as pegadas de Walter Benjamin na perspectiva de tentarmos entender o que acarreta essa mudança, ou troca inconsciente de prioridade.

A narrativa é tecida no seio da experiência. O narrador retira desta 0 material necessário para sua arte, apropriando-se de sua própria experiência ou mesmo das que the foram legadas. Há um processo de incorporação de experiência pelos ouvintes da narrativa, criando-se dessa forma, uma espécie de elo comum. Não importa se a experiência foi vivida ou ouvida, de toda forma torna-se parte de quem a ouve/absorve.

Mestrando em Filosofia no CMAF (Mestrado Acadêmico em Filosofia) da Universidade

Estadual do Ceará (UECE). Brasileiro, residente em Fortaleza -CE. Email: 
Para nosso pensador, "o romancista segrega-se". O romance mostra o indivíduo isolado, aquele que minimamente não consegue dar nem receber conselho algum, pois a capacidade narrativa, articulação/verbalização de experiência se atrofiou. "Escrever um romance significa, na descrição de uma vida humana, levar o incomensurável a seus últimos limites. Na riqueza dessa vida e na descrição dessa riqueza, o romance anuncia a profunda perplexidade de quem a vive" (BENJAMIN, 1985, 201). Tudo isso representaria, segundo nos parece, uma completa afirmação da "falta de sentido da vida" na Modernidade.

\begin{abstract}
A tradição oral, patrimônio da poesia épica tem uma natureza fundamentalmente distinta da que caracteriza o romance. $O$ que distingue o romance de todas as outras formas de prosa - contos de fada, lendas e mesmo novelas - é que ele nem procede da tradição oral nem a alimenta. Ele se distingue, especialmente, da narrativa. $\mathrm{O}$ narrador retira da experiência o que ele conta: sua própria experiência ou a relatada pelos outros. $E$ incorpora as coisas narradas à experiência dos seus ouvintes. O romancista segrega-se. A origem do romance é o indivíduo isolado, que não pode mais falar exemplarmente sobre suas preocupações mais importantes e que não recebe conselhos nem sabe dá-los. (BENJAMIN, 1985, 201)
\end{abstract}

"O romancista separou-se do povo", afirma Benjamin $(1985,55)$ em $A$ crise do romance. O narrador, no meio do povo, se afirmava infinitamente. $O$ Romance não nasce da tradição oral nem de forma alguma a possibilita. $O$ romancista mostra o indivíduo solitário e isolado, sem conexão com as coisas ao seu redor. Um aspecto devemos destacar: o romance só tem terreno fértil a partir da invenção da impressão. A impressa inaugura um novo período nas relações de produção.

A partir da impressa floresce um elemento que só poderia ser manifesto com a rapidez dos dias: a informação. Benjamin atribui a essa forma de comunicação o fator mais decisivo que operou em enfraquecer a arte narrativa. Com o avanço do capitalismo, as coisas e a vida foram aumentando a velocidade gradativamente. Se andamos a pé dentro de um parque, enriquecemos o nosso olhar com as mais belas imagens que construímos e acessamos. Mas, se, pelo contrário, fazemos uso de um carro em alta velocidade, muita coisa importante se perde.

Mestrando em Filosofia no CMAF (Mestrado Acadêmico em Filosofia) da Universidade Estadual do Ceará (UECE). Brasileiro, residente em Fortaleza -CE. Email: 
Com o jornal, sustentáculo da informação, não é muito diferente. Segundo nosso pensador, na sua estrutura, o jornal faz com que os saberes que vem de longe - espacial ou temporalmente -, e que poderiam ser grandiosas, como valores e ensinamentos de uma dada tradição perdem o seu valor. Ao passo que as coisas corriqueiras do dia a dia se tornam imprescindíveis.

Esses valores vindos de longe eram carregados de autoridade. Havia neles um teor de verdade. No Fedro, Platão indaga a seus interlocutores para evocar o valor do que vem longínquo temporalmente: "já ouviu contar uma história dos homens de antigamente. Eles conheciam a verdade. Se pudéssemos descobri-la, ainda nos importaríamos com a opinião dos homens? Fedro (274c).

A informação necessita de verificação imediata. Benjamin relata que o fundador do famoso jornal Le Figaro soube sintetizar a essência da informação quando diz que: "Para meus leitores", costumava dizer, "o incêndio num sótão do Quartier Latin é mais importante que uma revolução em Madri". (BENJAMIN, 1985, 202)

\begin{abstract}
O saber, que vinha de longe - do longe espacial das terras estranhas, ou do longe temporal contido na tradição -, dispunha de uma autoridade que era válida mesmo que não fosse controlável pela experiência. Mas a informação aspira a uma verificação imediata. Antes de mais nada, ela precisa ser compreensível "em si e para si". Muitas vezes não é mais exata que os relatos antigos. Porém, enquanto esses relatos recorriam frequentemente ao miraculoso, é indispensável que a informação seja plausível. Nisso ela é incompatível com o espírito da narrativa. Se a arte da narrativa é hoje rara, a difusão da informação é decisivamente responsável por esse declínio. (BENJAMIN, 1985, 202)
\end{abstract}

Em $O$ narrador, podemos observar que todos os dias somos bombardeados por notícias, que nos chegam de todos os cantos do mundo. Nosso autor, no entanto, nos revela ainda em 1936, que apesar disso, há uma grande pobreza de histórias verdadeiramente surpreendentes.

Como é possível se ter acesso a uma gama de histórias e ainda assim não ser afetado nem surpreendido por elas? Isso se deve ao fato das 
informações já virem acompanhas de explicação. Não é muito difícil ver nos jornais (e mesmo dentro do romance), uma descrição desmedida de tempo e espaço que não sobra nada para a imaginação do leitor, ou mesmo não sobra nenhum elemento que estimule a capacidade imaginativa.

A narrativa, se opõe drasticamente a isso. Benjamin revela que parte dos artifícios da arte de narrar se deve justamente a evitar dar maiores explicações.

Quando Hesíodo ${ }^{5}$ evoca as musas para que ele consiga cantar a origem dos deuses, elas sabem todas as histórias, relatam ao agricultor que sabem - e podem também muitas mentiras contar que se assemelham a verdade. "Sabemos muitas mentiras dizer semelhantes a coisas autênticas $\mathrm{E}$ sabemos, quando queremos, verdades proclamar" (BRANDÃO. 2000, 7)

A narrativa lida com o miraculoso, com o magnifico. Não requer nenhuma justificação para sua aceitação. Há em seu amago algo de profundo e verdadeiro, como os ensinamentos morais das fabulas. O processo de contemplação se dá no ato de imaginar as coisas e relações mágicas.

Cada manhã recebemos notícias de todo o mundo. E, no entanto, somos pobres em histórias surpreendentes. A razão é que os fatos já nos chegam acompanhados de explicações. Em outras palavras: quase nada do que acontece está a serviço da narrativa, e quase tudo está a serviço da informação. Metade da arte narrativa está em evitar explicações. (BENJAMIN, 1985, 202)

O fato de evitar explicações acaba enriquecendo as narrativas com sentidos e significados. Quando direcionamos nossos olhares para os mitos recebemos no mínimo duas visões de caráter temporal. Para as civilizações antigas, elas serviam para justificar a vida, a natureza e seus elementos. Os mitos dotavam de divindade cada coisa no mundo para melhor compreende-la e harmonizar-se com ela.

\footnotetext{
${ }^{5}$ Camponês Grego. É atribuído a ele dois grandes textos que são basilares para a formação grega: A Teoginia e Os trabalhos e os dias.
}

Mestrando em Filosofia no CMAF (Mestrado Acadêmico em Filosofia) da Universidade

Estadual do Ceará (UECE). Brasileiro, residente em Fortaleza -CE. Email: 
Mas hoje, somos mais analíticos com relação aos mitos. Eles hoje não nos explicam nada, mas nós os ressignificamos. Servem como uma imagem para justificar algo. Mobilizamos os mitos para justificar o complexo de Édipo, a exemplo da Psicologia. Adorno e Horkheimer, na Dialética do Esclarecimento, comentam a cena da Odisseia em que Ulisses é amarrado ao mastro do navio para que possa se deliciar com o cântico das sereias. Em contrapartida todos os seus guerreiros estão com cera no ouvido para não serem hipnotizados e levados a morte. Essa figura é interpretada por esses grandes nomes da Escola de Frankfurt, como sendo, a imagem de Ulisses, o semblante do homem burguês moderno, que se delicia com os prazeres da arte, sem poder entregar-se completamente. Ao passo aos trabalhadores - os guerreiros - é negado esse direito.

Fizemos todo esse percurso do mito e suas - possíveis - significações para demonstramos algo que para Benjamin é caro: a concisão da narrativa. Ele nos mostra que Heródoto era muito conciso em suas histórias. E essas histórias tem a capacidade de perpassar o tempo ainda repletas de revelações.

\begin{abstract}
Heródoto não explica nada. Seu relato é dos mais secos. Por isso, essa história do antigo Egito ainda é capaz, depois de milênios, de suscitar espanto e reflexão. Ela se assemelha a essas sementes de trigo que durante milhares de anos ficaram fechadas hermeticamente nas câmaras das pirâmides e que conservam até hoje suas forças germinativas. (BENJAMIN, 1985, 204)
\end{abstract}

Essa concisão se opõe as análises psicológicas, segundo Benjamin. Entra em cena o papel da memória, presente na narrativa, que é - também, mas não só - problematizada em $O$ narrador. A memorização de uma narrativa independe de analises psicológicas. Por analises psicológicas entendemos descrição profunda e detalhada das personagens de uma narração. Isso, pelo contrário cabe completamente na estrutura do romance.

Quanto mais distante se encontra o narrador e o ouvinte dessas analises, tanto mais fácil será a assimilação dessa história à experiência do ouvinte, que a tornara coisa sua. Esse permitirá que seja possível repassar o que ouviu, pois efetivamente a narrativa estará gravada em sua memória. 
Talvez pareça um salto o que vamos sugerir a seguir. É exposto - ou proposto - por Walter Benjamin uma metáfora. Ele diz o seguinte: "Se o sono é o ponto mais alto da distensão física, o tédio é o ponto mais alto da distensão psíquica. O tédio é o pássaro de sonho que choca os ovos da experiência. $O$ menor sussurro nas folhagens 0 assusta. Seus ninhos - as atividades intimamente associadas ao tédio - já se extinguiram na cidade e estão em vias de extinção no campo." (BENJAMIN, 1985, 204) Tentemos, pois, interpretar esse jogo. Se estamos psiquicamente cansados, o tédio toma-nos conta. Benjamin diz, que há um hipotético pássaro de sonho - ou de sono -, este é o tedio. Este pássaro faz o trabalho de tentar chocar seus ovos, que são a experiência; tenta trazer a luz do mundo experiência, seu fruto.

Esse pássaro que é o tédio, é que conseguira dar vida à experiência. $\mathrm{E}$ esse barulho, que atrapalha o pássaro na cidade, nada mais é do que o som das maquinas trazendo a modernidade. É impossível efetivar a narração a partir do advento da modernidade, da ascensão do capitalismo. Se não há possibilidade de experiência, não há o que repassar por meio da oralidade. A arte da narração necessita da experiência, é ela quem é narrada como um presente ao ouvinte.

Por esse fato a memória também se torna incapacitada de ser evocada na modernidade. $O$ cansaço psíquico a atrofia. Nesse mote, três aspectos interdependentes são perdidos: a experiência, a narração e a memória. Não são perdidos, são jogados para fora do "trem" em movimento, pela falta de espaço.

Nada facilita mais a memorização das narrativas que aquela sóbria concisão que as salva da análise psicológica. Quanto maior a naturalidade com que o narrador renuncia às sutilezas psicológicas, mais facilmente a história se gravará na memória do ouvinte, mais completamente ela se assimilará à sua própria experiência e mais irresistivelmente ele cederá à inclinação de recontá-la um dia. Esse processo de assimilação se dá em camadas muito profundas e exige um estado de distensão que se torna cada vez mais raro [...] Com isso, desaparece o dom de ouvir, e desaparece a comunidade dos ouvintes. Contar histórias sempre foi a arte de contá-las de novo, e ela se perde quando as histórias não são mais conservadas. Ela se perde porque ninguém mais fia ou tece enquanto ouve a história. Quanto mais o ouvinte se esquece de si mesmo, mais profundamente se grava nele o que é ouvido. Quando o ritmo do trabalho se apodera dele, ele escuta as histórias de tal Mestrando em Filosofia no CMAF (Mestrado Acadêmico em Filosofia) da Universidade

Estadual do Ceará (UECE). Brasileiro, residente em Fortaleza -CE. Email: 
maneira que adquire espontaneamente o dom de marrá-las. Assim se teceu a rede em que está guardado o dom narrativo. E assim essa rede se desfaz hoje por todos os lados, depois de ter sido tecida, há milênios, em torno das mais antigas formas de trabalho manual. (BENJAMIN, 1985).

É denunciada por Walter Benjamin, a falta de uma série de elementos que circulam a arte de narrar, como a comunidade artesanal, a sabedoria, a memória, o tedio, a experiência. Esses elementos estão desaparecendo com o surgimento dos tempos modernos ditado pela aceleração das condições de vida, com o império da máquina. Falar nesse atrofiamento, não é nenhum tipo de mobilização nostálgica. Como no caso da perda da arte de narrar, Benjamin anuncia modificações operadas pelo desenvolvimento técnico que causam uma reconfiguração nos modos de vida e de relacionamento entre os indivíduos. Se trata, no entanto, de entender que processos se passam nessas perdas e como podemos conviver ou resistir a eles, convertendo-os em provimento à sobrevivência.

\section{REFERÊNCIAS}

ADORNO, Theodor W, HORKHEIMER, Max. A dialética do esclarecimento. Rio de Janeiro: Jorge Zahar Editor, 1995.

BENJAMIN, Walter. "Experiência e Pobreza". in:__Magia e Técnica, Arte e Política. São Paulo: Brasiliense, 1985.

BENJAMIN, Walter. "O narrador - Considerações sobre a obra de Nikolai Leskov" In:_ Magia e Técnica, Arte e Política. São Paulo: Brasiliense, 1985.

BRANDÃO. Jacyntho Lins. As musas ensinam a mentir. Estudos Clássicos em Debate, Portugal: Revista Ágora, 2000.

HOMERO. Ilíada. Tradução Lourenço, F. São Paulo: Companhia das Letras/Penguin, 2013.

Odisseia. Tradução Jaime Bruna. São Paulo. Editora Cultrix. 2013.

JONES, Peter. Introdução. Homero. llíada. Tradução Lourenço, F. São Paulo: Companhia das Letras/Penguin, 2013. 
LUKÁCS, Georg. A Teoria do Romance. São Paulo. Editora 34. 2007. Pág. 68. 